\title{
FOREIGN MEDICAL MISSIONS IN SERBIA IN THE FIRST WORLD WAR
}

During the First World War, from 1914 until 1915, Serbia has been subjected to aggression and occupation by the Austro-Hungarian Empire. During the entire period of aggression and occupation, the Austro-Hungarian army and the local authorities carried out severe war crimes against wounded, sick, medical personnel and the civilian population. In addition to the aforementioned in the year of 1915, a major epidemic of all three types of typhoid occurred in Serbia. Because of the war and epidemic of typhoid the medical situation in Serbia was very difficult so a large number of medical missions from Allied and neutral countries have come to Serbia to help. The medical missions came from Russia, Great Britain, Canada, Greece Australia and New Zealand, as well as from neutral countries such as Switzerland, the USA, Netherlands and Denmark. These medical missions have managed to provide great assistance in rescuing wounded and sick in Serbia. Also, a large number of doctors and medical personnel from these missions have died or suffered from infectious diseases.

Keywords: First World War, Austro-Hungary, military hospitals, wounded, sick, medical personnel.

Faculty of International Politics and Security, Union - Nikola Tesla University, Belgrade, Serbia, jelena.lopicic@vektor.net

** Faculty of Geoeconomics, Megatrend University, Belgrade, Serbia, vasic_ljubica@yahoo.com 


\section{Introduction}

Austro-Hungary carried out an aggression against Serbia, announcing the war on $28^{\text {th }}$ July 1914 . As early as the first day of the aggression, Austro-Hungary began committing war crimes against the civilians by bombing Belgrade from its river monitors.

During these bombings from the Austro-Hungarian monitors, non-selective targets were targeted, primarily civilian. Many residential buildings, commercial buildings, electric power plants, plumbing installations, shops, schools, gymnasiums, faculties, hospitals, churches, as well as several other infrastructure facilities that had nothing to do with military facilities and military targets were destroyed. ${ }^{1}$ In these bombings from the Austro-Hungarian monitors, several thousand of civilian population were killed and wounded in their apartments, houses, markets, or streets. It is the fact that at that time Serbian army did not have a suitable and effective artillery to defend itself and to oppose these bombings from the Austro-Hungarian monitors. Nevertheless, with the existing artillery, the Serbian army managed to disable two monitors.

Belgrade as the capital of, at that time, the Kingdom of Serbia was a border town separated only by the rivers Sava and the Danube from the Empire of Austro-Hungary. This unfavorable border location of the city of Belgrade was a very easy target for Austro-Hungarian aggression and artillery bombing toward the Kingdom of Serbia. On the $28^{\text {th }}$ July, 1914 the Serbian government decided that the Government, the Assembly, the Court and the Supreme Command is to be transferred from Belgrade to Nis, which was the Serbian war capital until the withdrawal of the Serbian army in October 1915 through Albania and Montenegro. Before this decision was made, the city of Nis had about 30,000 inhabitants. By this decision the population grew to over 140,000 inhabitants in city of Nis, because in addition to the entire state administration and army, the largest military hospitals in Nis was located, as well as a large number of civilian refugees from Belgrade and other Serbian border towns came. Following, over 70,000 of captured Austro-Hungarian soldiers were stationed in collection centers in Nis and the surrounding area. ${ }^{2}$ There was also a diplomatic corps of allied foreign states in Nis that was accredited in Serbia and that retreated with the Serbian army through Albania and Montenegro. ${ }^{3}$

Vicić Snežana (2015): Beograd in Great War 1914-1918, Medija centar “Odbrana”, AteljeVicić, Beograd,pp. 20-24.

$2 \quad$ Hrabak Bogumil (1964): Austro-ugarski zarobljenici u Srbiji 1914-1915. godine prilikom povlačenja kroz Albaniju, Zbornik Historijskog instituta br. II, Slavonski Brod, p. 107.

3 Protić Stojan (1995): Niš-druga prestonica Srbije, Prosveta, Niš, p.3-54; Bop Ogist (1918): Za srpskom vladom od Niša do Krfa 20. oktobar 1915-19. januar 1916, Prevod s francuskog, Ženeva, pp.28-50; Opačić Petar (2015): Od Beograda do Krfa 1915-1916, Prometej Novi Sad, Radio-televizija Beograd; Novi Sad, Beograd, pp.35-70 
Throughout the First World War, the Austro-Hungarian Empire and Bulgarian army committed war crimes against civilians, medical personnel, prisoners of war, wounded and sick. Austro-Hungary had implemented the anti-Serb policy since 1906, ${ }^{4}$ and in 1908 prepared a war plan for the attack on Serbia, only waiting for a convenient opportunity to execute this plan. ${ }^{5}$ Austro-Hungary used the July crisis that arose after the Sarajevo assassination on $28^{\text {th }}$ June, 1914 to commit aggression against Serbia with the full support of Germany. Namely, Germany advised Austro-Hungary to immediately launch an attack on Serbia without any further delay because the opportunity has come as "now or never." In addition to the aforementioned, Germany and above all, Kaiser Wilhelm II estimated that if Austro-Hungary attacked Serbia, Russia and France will not be ready to defend Serbia, because it would provoke a war of larger proportions. Germany also thought that Great Britain would be neutral, although in their military plans they had aggression against Belgium as well as aggression against France, which was later realized. It is understood that the Austro-Hungarian Empire and Germany conducted unprecedented propaganda, and in advance proclaimed Serbia and Russia guilty of the outbreak of this First World War. ${ }^{6}$ Austro-Hungary planed the war against Serbia of local character and that during few days, will defeat Serbia.

However, the estimates and plans of Austro-Hungary and Germany in terms of the duration of what they planned for the local war had first turned into a European one, and then the World War which was the largest and bloodiest war in human history until that time, in which countries from America, Asia, Africa and Australia were included. Until 1939, this war was called the "Great War" (La Grande Guerre, The Great War, der Grosse Krieg). The number of the victims, the soldiers, and prisoners of war, wounded, sick, shipwrecked and civilian population had overcome all previous wars. Following was the destruction of the economy, industry, infrastructure, cultural goods were enormous and terrifying.

At the end of the Nineteenth and the beginning of Twentieth century, the military and war industry made enormous and unprecedented development, primarily in the mining range from artillery to infantry, various bombs, the appe-

Sretenović Stanislav (ed) (2016) Sa spskom vadom i vojskom od Niša do Krfa 1915-1916. francuska svedočanstva (Ogist Bop, Pjer-Viktor Furnije, Anri Barbi, Raul Labri, Luj Tomson, Marsel Dinan, Lisijen Piaron de Mondezir, Emil Vita) Novi Sad, Beograd, Prometej Novi Sad, Institut za savremenu istoriju Beograd, Radio-Televizija Beograd, pp.20-80

4 Ćorović Vladimir (1992): Odnosi između Srbije i Austro-Ugarske u XX. veku, Biblioteka grada Beograda, pp.666-788.

5 Opačić Petar (1994): Politika genocida Austrougarske protiv Srba u Prvom svetskom ratu, Vojnoistorijski glasnik No.1-2,Beograd,pp.48-50;Mitrović Andrej (2011): Srbija u planovima Austro-Ugarske i Nemačke 1908-1918,Beograd, pp. 80-130.

6 Trifković Srđa (2014): Julska kriza 1914. zajednički zločinački poduhvat Centralnih sila, Prvi svetski rat, Zbornik radova Međunarodna naučna konfrencija Beograd, 6-7. decembar 2011,Beograd,pp. 352-356

Vol. 16, № 3, 2019: 15-30 
arance of tanks, long-range artillery, planes, submarines and torpedoes, large armored ships, machine guns and rifles, the use of flame throwers, underwater mines at sea and rivers and the use of combat poisons. Due to this rapid development the number of war casualties and armed conflicts, as well as the destruction of economic and infrastructural facilities, including civilian objects, was catastrophic.

In addition to the above mentioned, the manner of warfare in the First World War was entirely new. First of all, tens of millions of soldiers were mainly sent to Trench warfare. This Trench warfare had major shortcomings because there were no conditions for the normal life of soldiers on the front lines. As a result, a large number of soldiers died or were wounded because they were unable to protect themselves from heavy artillery fire in the trenches. The Trench warfare lasted for years, and very few lines of the front line moved forward to create a series of difficulties. First of all, the sanitary conditions in the Trench warfare were catastrophically bad because the soldiers did not have any protection against rain, snow, cold and other weather conditions. There were only a very small number of covered earth shelters but they were reserved only for the command staff and the link service. Even these earth shelters did not provide protection against artillery bombing, they protected the soldiers only from rain and storms. Hygienic conditions were also catastrophic and created conditions for very fast and frequent occurrences of various epidemics, ranging from typhoid, diphtheria, dysentery, tuberculosis etc. Mice, rats, various insects were spreading rapidly, transmitting contagious diseases. The consequences were catastrophic and the army from both sides were decimated. It is estimated that the entire network of trenches on both sides of the war was about 40,000 kilometers, which undoubtedly indicates what kind of new technique and method of warfare were used, and how many millions of soldiers were in these terribly inhumane conditions for years.

The fact that the medicine at that time did not have effective medicaments to fight the above-mentioned epidemics, caused a high mortality of soldiers. Although there were vaccines against some infectious diseases, they were insignificant and very few were used because of war conditions so that they could not influence the prevention of these epidemics. The above-mentioned epidemics were also rapidly transmitted to the civilian population and as a consequence many have died.

In all belligerent countries, the existing civilian and military medical services were unable to provide close medical assistance and care to wounded and sick people. Because these medical services were not foreseen and formed for millions of armies as well as for hundreds of thousands of wounded and sick soldiers and civilians. The number of doctors and other medical personnel was relatively small on both belligerent parties, and they could not objectively provide minimum medical assistance and care. In addition, a large number of 
doctors and other medical personnel suffered from hostile bombings, especially because the Central Forces bombarded hospitals ambulances and other medical facilities, although they were visibly marked with Red Cross and were internationally protected from use of force and bombardment. Many doctors and medical personnel's were killed or wounded from bombing and number of doctors and medical personnel suffered from above mentioned epidemics.

For the first time in the history of warfare, poison and poisoned weapons were employed during the First World War, although the use of poison in warfare was banned by international law under the Convention respecting the Laws and Customs of War on Land (IV Hague Convention of 1907) and the Regulations Respecting the Laws and Customs of War on Land Section II Hostilities in Article 23, under the title Means of Injuring the Enemy, Sieges and Bombardments, paragraph 1 is stated:" In addition to the prohibitions provide by special Conventions, it is especially forbidden(a) To employ poison or poisoned weapons."7 Although all belligerent parties in the First World War signed and adopted the aforementioned Convention respecting the Laws and Customs of War on Land (IV Hague Convention of 1907) and the Regulations Respecting the Laws and Customs of War on Land they severely violated it.

During the fight against the Germans in August 1914, the French army used the chemical weapons artillery shells with tear gas. Following, on $22^{\text {nd }}$ April, 1915 the German army massively used combat poisons (chlorine) at the Belgian city of Ypres. In the same city of Ypres, the German army used a new poisonous gas on $12^{\text {th }}$ July 1917 which was named " Mustard Gas or Yperite "Practically all parties used poisons as war weapons. More than 1,296,000 people were killed or wounded from the use of combat poisons. Injuries from poisoning were eye injuries, often blindness, choking...The defense against poisoning was bad because the existing gas masks were unreliable. ${ }^{8}$

Austria-Hungary and Bulgaria did not use poison during the aggression against Serbia in the First World War, but they did use a number of other prohibited weapons against the Serbian army and civilian population, which will be discussed later.

Austro-Hungary and Bulgaria were signatories of the International Convention Respecting the Laws and Customs of the War on Land in 1907 (Hague Convention IV) and Regulations concerning the Laws and Customs of War on Land of 1907, and two Declarations -Declaration St. Petersburg Renouncing the Use in time of War of Explosive Projectiles Under 400 Grams Weight of 1868, (Declaration of St. Petersburg, in 1868) and Declaration concerning the Prohibition

Predić Vesna et al. (eds) (2007): Izvori međunarodnog humanitarnog prava, Međunarodni komitet Crvenog krsta, Beograd, p. 311

$8 \quad$ Krivokapić Boris (2010): Enciklopedijski rečnik međunarodnog prava $i$ međunarodnih odnosa, Službeni glasnik, Beograd, pp. 330-331; Perazić Đ. Gavro(1986): Međunarodno ratno pravo, Vojnoizdavački i novinski centar, Beograd,pp. 159-163

Vol. 16, № 3, 2019: 15-30 
of the Use of Bullets which can Easily Expand or Change their Form inside the Human Body such as Bullets with a Hard Covering which does not Completely Cover the Core, or containing Indentations (the Third Declaration of the Hague of 1899) and the each side ratified these documents and were obliged to adhere to the above mentioned Conventions and Declarations, as well as to the existing international customary law of war. ${ }^{9}$

However, Austro-Hungary as well as Bulgaria, during the occupation of Serbia, also performed systematic and severe war crimes against civilians, medical personnel, prisoners of war, wounded and sick. ${ }^{10}$ Aside from Austro-Hungarian and Bulgarian army, war crimes were also committed by Turkish army. Although Serbia was not in direct armed conflict, because it was not a neighboring country, Turkey made secret agreement with the Austro-Hungary on the extradition of Serbian prisoners of war, wounded and sick from the Austro-Hungarian concentration camps. As result of this secret agreement 5,000 Serbian inmates were transferred to Turkey. In Turkish concentration camps, as well as in mines, half of these inmates lost their lives. ${ }^{11}$

One of the most serious violations of the abovementioned international Conventions (IV Hague Convention of 1907) and (Regulations of 1907) from the side of Austro-Hungary and Bulgaria was the mass arrest of the civilian population (elderly people, women and even children) that were sent to various concentration camps in Austro-Hungary. The abovementioned persons could not, under any international convention or under customary international law, be declared as prisoners of war. In these concentration camps the conditions of accommodation, nutrition, hygiene, and medical care were very poor and difficult. Accommodation in improvised wooden shacks without basic hygienic conditions, followed by starvation, lack of heating during the winter period caused massive freezing and eventual death. Typhus, typhoid, tuberculosis, diphtheria and other infectious diseases had also appeared, leading to the deaths or serious injury of the health of inmates. It was estimated that there were over 200,000 Serb inmates in the concentration camps, half of which died. ${ }^{12}$

During the First World War (1914-1918) the Austro-Hungarian army used explosive ammunition in Serbia, which was banned by international law- Dec-

$9 \quad$ Les deux Conference de la Paix 1899. et 1907. Recueil des Textes arretes parces Conferences et de differents, Documents complementaires, (1909); Paris,p. 62.

$10 \quad$ Reiss Archibald (1995): Izveštaj podnesen srpskoj vladi o zverstvima koja je austrougarska vojska počinila za vreme prvog upada u Srbiju, Beograd-Gornji Milanovac, p. 7

11 Ćuković Isidor (2001): Srpski ratni zarobljenici u Turskoj 1917-1918.godine,Vojnoistorijski glasnik No.1, Beograd, p. 80.

12 Topalović Živko (1918): Za naše zarobljenike, Krf, p. 8-10; Stojančević Vladimir (1975): Srpski civilni internirci u Austro-Ugarskoj za vreme Prvog svetskog rata, Istorijski časopis XXII, Beograd, p. 152-168; Denda Dalibor (2015):Srpski ratni zarobljenici u Velikom ratu, Prvi svetski rat, Srbija, Balkan i velike sile, Istorijski institut u Beogradu, Beograd p. 269-282. 
laration of St. Petersburg of $1868,{ }^{13}$ and the Third Hague Declaration of $1899 .{ }^{14}$ The use of these prohibited explosive ammunition caused great mortality as well as very serious wounding that in most cases ended with death or amputations of body parts (arms or legs). ${ }^{15}$

\section{Medical and health situation in Serbia in 1914 and 1915}

Although the Austro-Hungary caused the First World War and carried out an aggression against Serbia, it constantly accused Serbia of being guilty for the outbreak of the First World War. At that point, Serbia was not ready for any kind of war, because it was military, financially and physically exhausted in the previous two Balkan Wars (1912-1913). During the two Balkan wars, Serbia fought for liberation from Turkish slavery, therefore, war torn Serbia did not have the financial means to renew the army, nor did it have the means for proper medical service. In 1914, the military medical service of the Kingdom of Serbia had 534 doctors and several hundred medical assistants and nurses, as well as 203 mobilized medical students. Military hospitals were located in Belgrade, Nis, Valjevo, Kragujevac and Zajecar. There were also 24 emergency hospitals and 58 temporary hospitals. ${ }^{16}$

It is quite certain that the Serbian medical and military service was not sufficient to provide adequate medical care to tens of thousands of wounded and sick soldiers and civilians. Even a large number of volunteer nurses, medical assistants and personnel were not enough to provide adequate medical care. There was also a relatively small number of hospitals and health facilities for operation of military hospitals. Because of this these military hospitals and ambulances were mostly improvised, since they were located mostly in elementary schools, gymnasiums, various warehouses, hotels, private houses, other unfinished premises or tents. One of the basic problems of these improvised hospitals was the lack of basic conditions for normal medical work. Lack of medicaments and other medical supplies was acute, making it difficult for wounded and sick people to be treated. Then, the hygienic conditions were very poor, which led to the occurrence of various major or minor infections and epidemics. All of these disadvantages had consequences for increasing mortality in wounded and sick people.

13 Rules of International Humanitarian Law and Other Rules Relating to the Conduct of Hostilities, Collection of treaties and other instruments, (2005): International Committee of the Red Cross, Geneva p.159-160.

14 Petković Boško (ed.) (1979): Međunarodne konvencije o ratnom pravu i o sigurnosti, Zavod za općenarodnu i društvenu samozaštitu SRH,Zagreb, p. 312.

15 Tinhoven van Arijus (2005): Strahote rata u Srbiji dnevnik ratnog hirurga 1915, Utopija, Beograd,pp. 44-51

16 Nedok S.Aleksandar, Popović Branislav (2010): Srpski vojni sanitet 1914-1915. godine, Ministarstvo odbrane Republike Srbije, Uprava za vojno zdravstvo, Akadamija medicinskih nauka srpskog lekarskog društva, Beograd pp.38-67

Vol. 16, № 3, 2019: 15-30 
It is known that in wars and armed conflicts doctors and medical personnel are needed, because most of the wounds need to be treated immediately. Also conditions in operating rooms and ambulance need the help of qualified medical assistants and nurses. In large number of cases, when soldiers or civilians were injured, an emergency surgical intervention was required which, if delayed, can result in death or severe infections and complications. Unfortunately due to lack of medical personnel this was a frequent occurrence during the war. Also the lack of epidemiologist during the first years of war resulted in decimation of sick and wounded solders and civilians.

The special difficulty of the Serbian army and the military service in the First World War is the capture of about 60,000 Austro-Hungarian soldiers, which had to be placed in appropriate collection prisons, in order to provide guard services as well as medical assistance and care. Namely, among the mentioned Austro-Hungarian prisoners of war, there were a number of wounded and sick as well as a very small number of Austro-Hungarian medical personnel. A part of the Austro-Hungarian prisoners were infected with a typhus that quickly transferred to the Serbian army and spread to the civilian population.

During the First World War Serbia lost one third of its population and $26 \%$ of soldiers, and it was the first in terms of those losses from all participants in that war. ${ }^{17}$ In addition to the losses from wounding in fighting, as well as the suffering in numerous concentration camps, in Serbia during the period between 1914 and 1915, the typhus epidemic occurred. All three types of typhus disease occurred: typhus exanthematicus, typhus abdominal and febris recurrens. The consequences were catastrophic: 35,000 soldiers died, over 100,000 civilians as well as 132 doctors of a total of $534 .{ }^{18}$ As we mentioned earlier the typhus was brought by captured Austrian soldiers who were infected and the epidemic spread to the Serbian army, medical personnel and civilians, which resulted in the decimation of Serbian soldiers and civilian population. In addition to the typhus epidemic, there have also been epidemics of cholera, desertion, malaria and Spanish fever, estimated to have killed about 360,000 people. ${ }^{19}$

During 1915, the Serbian medical service started vaccinating against typhus and cholera, but this vaccination was interrupted because there was a withdrawal of the Serbian army together with the refugees at the end of 1915 and early 1916 through Albania and Montenegro. In that withdrawal, death from infectious diseases in the first two months continued on to Corfu, Lazarevac and Vida peninsulas. An epidemic of malaria followed when the Serbian army moved through the

\footnotetext{
17 Radojević Mira, Dimić Ljubodrag (2016): Srbija u Velikom ratu 1914-1918, Kratka istorija, Beogradski forum za svet ravnopravnih, Beograd,p. 259

18 Serbia in First World War- Available from: https://sr.wikipedia.org/Srbija_u Prvom_svetskom_ratu

19 Tschanz, D. W. (2008): Typhus Fever on the Eastern Front in World War I. Insects, Disease and History, Entomology Group of Montana State University.
} 
wetlands of Thessaloniki. The Serbian Army's vaccination as well as other preventive measures have been undertaken which has led to a reduction in the number of patients and a reduction in mortality and without serious consequences.

Through its diplomatic representatives abroad, Serbia successfully managed to inform European public its opinion about aggression, occupation, war crimes, as well as severe medical situation and epidemics. ${ }^{20}$ The result of the diplomatic actions of the Kingdom of Serbia was very quickly realized both on the political and on the humanitarian agenda. On the political plan, the public in the allied states, as well as the public in neutral countries, learned directly about the Austro-Hungarian aggression and occupation, as well as the catastrophic medical situation in Serbia, which resulted in adequate humanitarian assistance and aid. Several foreign authors published their very noteworthy books, brochures and articles in daily newspapers in foreign languages about the whole situation that they personally have seen and experienced in Serbia. It is impossible in this short paper to list all the authors who have written on the subject, so we will only mention some of them: Dr Archibald Ress, Catharina Clara Sturzenegger, Dr. Arius Van Tienhoven Henri Barbusse, Harold Temperley, Fortier Jones, Charles J. Vopicka and others.

\section{Foreign medical missions in Serbia}

In the period from 1914 to 1915, Serbia lacked mainly in medical doctors and medical personnel, as well as in medical supplies, medicines, hospital equipment, food, clothing, etc. Having in mind the large number of the sick and wounded. Serbia also lacked in surgeons, and later when the epidemics of infectious disease occurred also in epidemiologist and infectious disease specialists. It was a well-known fact that allies and friendly countries, as well as the neutral countries, have responded by sending great humanitarian aid in medicine, medical supplies, doctors, medical personnel and financial means (money).

Foreign medical missions that came to Serbia during the First World War were organized on several grounds. Namely, most of the medical missions were sent by the allies such as: Russia, Great Britain, France, Canada, Greece, Australia, New Zealand, which were military or civil medical missions. In addition to allied medical missions, there were also medical missions from the neutral countries (Switzerland, the United States, the Netherlands, and Denmark). There were plenty of medical missions from the listed countries that were sent by various medical and humanitarian associations. There were also a lot of smaller groups of doctors with their teams that came to Serbia following their personal

$20 \quad$ Lopičić Jančić Jelena (2014): Diplomatske aktivnosti Vlade Kraljevine Srbije sa ciljem upoznavanja međunarodne javnosti o okupaciji Srbije i ratnim zločinima izvršenim za vreme Prvog svetskog rata od strane Austrougarske i Bugarske,:Sto godina od početka Prvog svetskog rata, istorijske i pravne studije, Insitut za uporedno pravo, Beograd pp. 424-433

Vol. 16, № 3, 2019: 15-30 
initiative, as well as individuals who came to Serbia on their own initiative. Since there were relatively many foreign medical missions in Serbia in 1914 and 1915, and there were hundreds of doctors and other medical personnel, it is impossible to process them all in this short article. That is why we will, at our option, state some of these medical missions, which in our opinion should be stated.

Among the first medical missions that came to Serbia in 1914, there were medical missions from Russia. At the request of the Serbian government, the Serbian delegate in St. Petersburg Dr Miroslav Spalajkovic who organized several groups of Russian doctors and medical personnel who came to Serbia during August, September and October in 1914. A large amount of medical and hospital materials, medicines, clothes, hospital linen, and other equipment were delivered from Russia.

Russia has opened equipped hospitals in Valjevo and in the Nis - Moscow Surgical Military Hospital with 350 beds, as well as a hospital with 400 beds for the treatment of typhus exanthematicus. In Nis, a Russian-Serbian city medical help was established, which included the entire Russian disinfection team, as well as Russian doctors from Nis hospitals. Russia had established an orphanage for uninhabited children in Niska Banja. The Russian medical team remained in Nis until the autumn of 1915, when the Serbian army withdrew to Albania, and then they continued work in Russian medical facilities on the Thessaloniki front. The work of the Russian medical missions in several towns of Serbia was very significant and important, as Russian doctors and medical personnel gave medical assistance not only to the Serbian army, but also to the civilian population who were subjected to bombing, wounding and contagious diseases as well as the army. It was important and very successful health action of the Russian medical mission that managed to stop the typhus epidemic in several cities in Serbia where they were accommodated.

The then modern medical science was first confronted in the First World War with large epidemics. There was no single view of how to prevent spreading of these infectious diseases, primarily typhoid, who was the transmitters of these infectious diseases. There were various opinions, but in practice during the half year of the First World War they were largely unsuccessful so that epidemics of typhoid typhus in various countries decimated the army and civilian population. An epidemic of typhoid typhus transmitted by the Austro-Hungarian prisoners was suppressed in June 1915.

From allied countries, Great Britain was one of the first to send medical missions to Serbia in December of 1914. The special place belongs to the nongovernmental organization Scottish Women's Hospitals, which was founded and managed by the famous Scottish doctor Elsie Maud Inglis who was the greatest heroine of the First World War. ${ }^{21}$ The first hospital of Scottish women who had

$21 \quad$ Elsi Inglis (1864-1917); British doctor and humanitarian worker. She organised 14 medical units for humanitarian service in France, Serbia, Corsica, Thessaloniki front, Romania, 
100 beds arrived in Serbia in December of 1914. The hospital consisted of 30 women, 5 of whom were doctors, 24 nurses and one ambulance driver. During 1915, other British medical units were also sent to Serbia, which were located in Mladenovac, Valjevo, Lazarevac and Vrnjacka Banja. ${ }^{22}$

During a major typhus exanthematicus epidemic in May of 1915, doctor Elsi Inglis arrived in Kragujevac with a group of medical staff. With the control of the Austro-Hungarian occupier, she withdrew with the hospital staff to Krusevac, where she received the Austrians in November 1915 and refused to leave the hospital with 300 sick and wounded. She had the great courage to wait for Austro-Hungarian occupier and then to refuse to leave the hospital with 300 patients and wounded. The Austro-Hungarian occupier could simply do what they have done in countless cases, to send all of them to one of the concentration camps of death where most of them died in a short period of time. The Austrians confiscated all the equipment in the hospital. Doctor Elsie Inglis continued with her medical team treating sick and wounded until February 1916, when the entire medical team was repatriated to the United Kingdom by the help of United States ambassador in Vienna.

The Dutch surgeon Arius van Tienhoven on personal initiative, with his small medical team, came to Serbia in 1914. Dr Arius van Tienhoven during the First World War was head of the surgical department of the Military Hospital in Valjevo where he was a very successful surgeon who saved many lives of the sick and wounded. His role was especially important because during the operations he noticed in many wounded patients that their wounds were inflicted by explosive bursting ammunition called "dum-dum". Such explosive and bursting ammunition was banned by the International law - Declaration concerning the Prohibition of the Use of Bullets which can Easily Expand or Change their Form inside the Human Body such as Bullets with a Hard Covering which does not Completely Cover the Core, or containing Indentations (the Third Declaration of the Hague of 1899). ${ }^{23}$ Dr Arius van Tienhoven, as a surgeon and a member of an international commission participated in the investigation of Austro-Hungarian war crimes committed in Serbia. Furthermore, Dr Arius van Tienhoven published his findings about committed war crimes in several articles that included photographs as early as 1915, introducing Austro-Hungarian war crimes to the world. ${ }^{24}$ In 1915 he also published the book under the title "The horrors of

Russia and Malta. For more information see: Srpski biografski rečnik 4. I-Ka, Novi Sad: Matica Srpska, 2009,p. 180-181.

22 Vučević Danijela, Djordjević Drago, Radosavljević Tatjana (2014); Stogodišnjica Velikog rata-lekari i bolničarke koji su zadužili srpski narod, Medicinski podmladak Izdanje 65,No.1-2, Beograd,pp. 84-86.

23 Predić Vesna et al. (eds) (2007); Izvori međunarodnog humanitarnog prava, Međunarodni komitet Crvenog krsta, Beograd, p. 376

24 Vuković Žarko (2009): 1915 Savezničke medicinske misije u Srbiji: Da ne zaboravimo, „Filip Višnjić”, Beograd,pp. 101-103

Vol. 16, № 3, 2019: 15-30 
the war in Serbia: Diary of the War Surgeon". We would like to underline that these important works have been published by Dr. Tinhoven much before Dr Archibald Ress.

The first US medical mission came to Serbia on $13^{\text {th }}$ September 1915, which consisted of dr Edward W. Ryan and 12 nurses. Just one month after the mission arrived in Belgrade, the Austro-Hungarian army occupied Belgrade. Several thousand patients have passed through this hospital, and more than a thousand of them have been infected with typhus exanthematicus. Dr Ryan himself was suffering from typhus exanthematicus, but luckily he managed to survive. Since in Belgrade there were no Serbian authorities or diplomatic representatives, $\mathrm{dr}$ Ryan took over the role of the American consul. Dr. Ryan managed to protect the Serbian civilians from the Austro-Hungarian authorities and to prevent the arrest of several Serbian representatives of the youth convicted by the AustroHungarian military court.

In 1915, France sent hundreds of doctors to Serbia who were deployed in several places. French doctors have been very successful in their struggle against infectious diseases that prevailed in Serbia at the time: typhoid, cholera, diphtheria and smallpox. Then, in mid-1915's, France sent several medical teams to Serbia. In November 1915, members of the French medical mission withdrew with the Serbian army through Albania.

\section{Conclusion}

Based on all of the above mentioned, we can conclude that numerous foreign medical missions helped with their medical and humanitarian activities in Serbia during the period between 1914-1915, when Serbia was in a desperate need of help. It was quite certain that the struggle against the great typhoid epidemic was the most difficult, that had decimated the Serbian population, the army, and the Serbian medical staff. Also, we would like to mention that foreign medical missions in Serbia also suffered from typhoid epidemic. There are no precise data on how many members of foreign medical missions died, but it was estimated that more than 100 people have died. Although our literature contains many sources on foreign medical missions in Serbia 1914-1915, in our opinion, many of the activities have yet to be researched. In 2018 we had the opportunity to celebrate one hundred years since the end of the First World War. In some of the defeated states of the Central Powers there were attempts to revise the First World War One in order to blame Serbia and Russia for the outbreak, the occupation, and the massacre. Such articles would be a modest contribution to the ratification of the Versailles Peace Agreement from 1919, where it is precisely stated who was the aggressor and who were the victims of the war, and that Serbia was a victim of war. 


\section{Literature:}

- Bop Ogist (1918): Za srpskom vladom od Niša do Krfa 20. oktobar 1915.- 19. januar 1916., Prevod s francuskog, Ženeva,

- Ćorović Vladimir (1992): Odnosi između Srbije i Austro-Ugarske u XX. veku, Biblioteka grada Beograda

- Ćuković Isidor (2001): Srpski ratni zarobljenici u Turskoj 1917-1918. godine,Vojnoistorijski glasnik No.1/2001, Belgrade, pp. 80-92

- Denda Dalibor (2015): Srpski ratni zarobljenici u Velikom ratu, Prvi svetski rat, Srbija, Balkan i velike sile, Istorijski institut u Beogradu, Belgrade p. 269282

- Hrabak Bogumil (1964): Austro-ugarski zarobljenici u Srbiji 1914.-1915. godine prilikom povlačenja kroz Albaniju, Zbornik Historijskog instituta br. II, Slavonski Brod, p. 107-16.

- Krivokapić Boris (2010): Enciklopedijski rečnik međunarodnog prava i međunarodnih odnosa, Službeni glasnik, Beograd

- Les deux Conference de la Paix 1899. et 1907. Recueil des Textes arretes parces Conferences et de differents, Documents complementaires, (1909): Paris

- Lopičić Jančić Jelena (2014): Diplomatske aktivnosti Vlade Kraljevine Srbije sa ciljem upoznavanja međunarodne javnosti o okupaciji Srbije i ratnim zločinima izvršenim za vreme Prvog svetskog rata od strane Austrougarske i Bugarske, Sto godina od početka Prvog svetskog rata, istorijske i pravne studije, Insitut za uporedno pravo, Belgrade pp. 419-433

- Mitrović Andrej (2011); Srbija u planovima Austro-Ugarske i Nemačke 19081918, Belgrade

- Nedok S.Aleksandar, Popović Branislav (2010): Srpski vojni sanitet 1914-1915. godine,Ministarstvo odbrane Republike Srbije, Uprava za vojno zdravstvo, Akadamija medicinskih nauka srpskog lekarskog društva, Belgrade

- Opačić Petar (2015): Od Beograda do Krfa 1915.-1916., Prometej Novi Sad, Radio-televizija Beograd; Novi Sad, Beograd,

- Opačić Petar (1994): Politika genocida Austrougarske protiv Srba u Prvom svetskom ratu, Vojnoistorijski glasnik No.1-2,Beograd, pp. 48-50

- Perazić Đ. Gavro(1986); Međunarodno ratno pravo, Vojnoizdavački i novinski centar, Beograd

- Petković Boško (ed.) (1979): Međunarodne konvencije o ratnom pravu i o sigurnosti, Zavod za općenarodnu i društvenu samozaštitu SRH, Zagreb

- Predić Vesna et al. (eds) (2007): Izvori međunarodnog humanitarnog prava, Međunarodni komitet Crvenog krsta, Beograd

- Protić Stojan (1995): Niš-druga prestonica Srbije, Prosveta, Niš

- Radojević Mira, Dimić Ljubodrag (2016); Srbija u Velikom ratu 1914-1918,Kratka istorija, Beogradski forum za svet ravnopravnih, Beograd 
- Reiss Archibald (1995): Izveštaj podnesen srpskoj vladi o zverstvima koja je austrougarska vojska počinila za vreme prvog upada u Srbiju, Beograd-Gornji Milanovac

- Rules of International Humanitarian Law and Other Rules Relating to the Conduct of Hostilities, Collection of treaties and other instruments, (2005): International Committee of the Red Cross, Geneva, p.159-160

- Serbia in First World War - Available from: https://sr.wikipedia.org/Srbija_u Prvom svetskom_ratu

- Sretenović Stanislav (ed) (2016), Sa spskom vadom i vojskom od Niša do Krfa 1915.-1916. francuska svedočanstva (Ogist Bop, Pjer-Viktor Furnije, Anri Barbi, Raul Labri, Luj Tomson, Marsel Dinan, Lisijen Piaron de Mondezir, Emil Vita) Institut za savremenu istoriju Beograd, Radio-Televizija, Beograd, Novi Sad, Beograd, Prometej Novi Sad

- Tinhoven van Arijus (2005): Strahote rata u Srbiji dnevnik ratnog hirurga 1915, Utopija, Beograd

- Topalović Živko (1918): Za naše zarobljenike, Krf, p. 8-10; Stojančević Vladimir (1975): Srpski civilni internirci u Austro-Ugarskoj za vreme Prvog svetskog rata, Istorijski časopis XXII, Beograd, p. 152-168

- Trifković Srđa (2014): Julska kriza 1914. zajednički zločinački poduhvat Centralnih sila, Prvi svetski rat, Zbornik radova Međunarodna naučna konfrencija Beograd, 6.-7. decembar 2011.,Beograd,

- Tschanz, D. W. (2008): Typhus Fever on the Eastern Front in World War I. Insects, Disease and History, Entomology Group of Montana State University

- Vicić Snežana (2015): Belgrade in Great War 1914-1918, Medija centar "Odbrana”, Atelje-Vicić, Beograd

- Vučević Danijela, Djordjević Drago, Radosavljević Tatjana (2014); Stogodišnjica Velikog rata-lekari i bolničarke koji su zadužili srpski narod,: Medicinski podmladak Izdanje 65,No.1-2, Beograd, pp. 79-86

- Vuković Žarko (2009): 1915 Savezničke medicinske misije u Srbiji: Da ne zaboravimo, "Filip Višnjić", Beograd 
Originalni naučni rad Primljen 10.04.2018.

Odobren 21.06.2018.

\section{STRANE SANITETSKE MISIJE U SRBIJI U PRVOM SVETSKOM RATU}

Tokom Prvog svetskog rata, a u periodu od 1914. do 1915. godine, Srbija je bila predmet agresije i okupacije od strane Austrougarskog carstva. Tokom čitavog perioda agresije i okupacije, austrougarska vojska i lokalne vlasti izvršile su teške ratne zločine protiv ranjenika, bolesnika, medicinskog osoblja i civilnog stanovništva. Pored navedenog, 1915. godine, u Srbiji je došlo do velike epidemije sve tri vrste tifusa. Imajući u vidu rat i epidemiju tifusa, zdravstvena situacija u Srbiji bila je veoma teška, tako da je veliki broj sanitetskih misija iz saveznih i neutralnih zemalja došao u Srbiju da pomognu. Sanitetske misije su došle iz Rusije, Velike Britanije, Kanade, Grčke, Australije i Novog Zelanda, kao i iz neutralnih zemalja kao što su Švajcarska, Sjedinjene Američke Države, Holandija $i$ Danska. Ove sanitetske misije uspele su pružiti veliku pomoć u spasavanju ranjenih $i$ bolesnih u Srbiji. Takođe želimo da pomenemo da je veliki broj doktora i medicinskog osoblja iz ovih stranih misija umro, ili je bio zaražen od zaraznih bolesti.

Ključne reči: Prvi svetski rat,Austorugarska, vojne bolnice, ranjenici, bolesnici, medicinsko osoblje. 